Chimia 46 (1992) 444-446

(c) Neue Schweizerische Chemische Gesellschaft ISSN $0009-4293$

\section{Are High Heats of Atomization for Many Oxides and Fluorides of $Z$ above 37 due to Enhanced Correlation Energy?}

\author{
Christian K. Jørgensen*
}

Abstract. Heats of atomization $H_{\mathrm{a}}$ (per atom) are compared for for 28 diatomic oxides, 14 diatomic fluorides, 26 solid and 2 polyatomic gaseous oxides, 9 solid and 5 polyatomic gaseous fluorides. There is no universal trend toward lower $H_{\mathrm{a}}$ with increasing $Z$ in a column of the Periodic Table; $d$-group, post-d-group, and partly filled $4 \mathrm{f}$ and $5 \mathrm{f}$ shells encourage smaller $H_{\mathrm{a}}$ but barium, lanthanum, lutetium, hafnium, tantalum, (to the largest extent thorium), and uranium show unexpected high $H_{\mathrm{a}}$. This 'Barium-Thorium Effect' can be rationalized by known facts of correlation energy in atoms and (light) compounds, possibly including indirect relativistic effects due to distorted $\mathrm{AO}$ in LCAO.

The enthalpies per atom of atomization $H_{\mathrm{a}}$ (i.e. sample separated to distant neutral atoms in their groundstate) of diamond and graphite are $7.5 \mathrm{eV}$ and of metallic elements varying from $0.64 \mathrm{eV}$ for mercury, $0.81 \mathrm{eV}$ for caesium, up to 8.0 to $8.2 \mathrm{eV}$ for rhenium and osmium, and $8.8 \mathrm{eV}$ for tungsten. It is worthwhile to consider heats of atomization $H_{\mathrm{a}}$ for compounds, and it seems that solid thorium (IV) oxide (melting at $3500 \mathrm{~K}$ and boiling (760 Torr) at $4700 \mathrm{~K}$ ) has the highest known value, $8.02 \mathrm{eV}$. The very large majority of compounds have $H_{\mathrm{a}}$ below 4 $\mathrm{eV}$. Among organic compounds, highly carbon-rich molecules (few 'single' bonds) show higher $H_{\mathrm{a}}$ such as $\mathrm{HCCH} 4.26$ and its trimer benzene $4.77 \mathrm{eV}$. It was pointed out [1] that only 14 diatomic molecules are known to have $H_{\mathrm{a}}$ above $4 \mathrm{eV}$ (or at least within a narrow interval of experimental uncertainty), that is $\mathrm{N}_{2}$ (4.90), $\mathrm{CN}$ (3.99), $\mathrm{BF}$ (3.97), and 11 monoxides among those given in the Table. Their order of $H_{\mathrm{a}}$

$\mathrm{CO}>\mathrm{N}_{2}>\mathrm{ThO}>\mathrm{BO} \sim \mathrm{HfO} \sim \mathrm{SiO} \sim$ $\mathrm{LaO} \sim \mathrm{TaO} \sim \mathrm{CeO}>\mathrm{ZrO} \sim \mathrm{NbO} \sim \mathrm{CN}$ $\sim \mathrm{BF} \sim \mathrm{UO}$

* Correspondence: Prof. K. Jørgensen Section de Chimie

30, Quai Ernest-Ansermet

CH-1211 Geneva 4 emphasizes that the chemistry of diatomics studied around $4000 \mathrm{~K}$ (in sunspots and in spectra of $\mathrm{M}$ - and S-type stars) differs entirely from inorganic chemistry in solids, liquids, and solution. Not a single oxidation state $\mathrm{M}$ (II) or $\mathrm{B}$ (I) that one might infer from series ( $l$ ) occurs in non-metallic, non-catenated inorganic solids [2][3]. The increasing importance of entropy at high $T$ pays a premium for the last step before monatomicity.

In this note, solid and gaseous binary compounds $\mathrm{M}_{\mathrm{A}} \mathrm{X}_{\mathrm{B}}$ are selected for comparison of unusually high $H_{\mathrm{a}}$ with some, more typical values. The heat of formation from the elements in their standard state, and $H_{\mathrm{a}}$ of $\mathrm{M}$ and $\mathrm{X}$ are taken from comprehensive compilations [4][5]. If the vapour of an element contains large amounts of oligomers ( $\mathrm{Si}, \mathrm{P}, \mathrm{Ge}, \mathrm{Sn}$, and even $\mathrm{Au}$ and Li), $H_{\mathrm{a}}$ may be considerably larger than the heat of evaporation.

$$
\begin{aligned}
& \mathrm{M}_{\mathrm{A}} \mathrm{X}_{\mathrm{B}} \rightarrow \mathrm{A} \mathrm{M}^{\text {stand }}+\mathrm{B} \mathrm{X}^{\text {stand }} \rightarrow \mathrm{A} \mathrm{M}^{0} \\
& +\mathrm{B} \mathrm{X}^{0} \\
& H_{\mathrm{a}}=\left\{(\text {-heat of formation })+\mathrm{A} H_{\mathrm{a}}(\mathrm{M})\right. \\
& \left.+\mathrm{B} H_{\mathrm{a}}(\mathrm{X})\right\} /(\mathrm{A}+\mathrm{B})
\end{aligned}
$$

where $\mathrm{M}^{0}$ and $\mathrm{X}^{0}$ indicate neutral gaseous atoms (in contrast to $\mathrm{Li}^{+}$and $\mathrm{F}^{-}$). It is evident that $E q n .2$ has given up the classical advantage that $H_{\mathrm{a}}$ of $\mathrm{M}^{\text {stand }}$ and $\mathrm{X}^{\text {stand }}$ are not needed, they may be known very imprecisely (or not at all). However, quan- tum chemistry encouraged this alternative approach. Fortunately, no neutral atoms at sufficient mutual distance decrease their energy by transfer of an electron (not even $\mathrm{Cs}^{0}$ and $\mathrm{Cl}^{0}$ ). Most well characterized compounds have negative heat of formation [4] and hence, the first parenthesis of $H_{\mathrm{a}}$ in Eqn. 2 is usually positive, like the two $H_{\text {a }}$ (M) and $H_{\mathrm{a}}(\mathrm{X})$. One must be aware that even colourless compounds [2] may exist as $(\mathrm{LiF})_{2},(\mathrm{CsI})_{3}, \mathrm{Ge}_{3} \mathrm{O}_{3}, \mathrm{~W}_{4} \mathrm{O}_{12}, .$. in vapours [5] (like unexpected ternary compounds such as $\left(\mathrm{ReO}_{4}\right)_{2} \mathrm{Ca}, \mathrm{MoO}_{4} \mathrm{Ba}_{2}$, and $\mathrm{MoO}_{3} \mathrm{Li}$ ).

It is a general feeling that both electrovalent bonding and covalency $\left(c f . \mathrm{H}_{2}>>\mathrm{Li}_{2}\right.$ $>\mathrm{Na}_{2}$ or $\mathrm{N}_{2}>\mathrm{P}_{2}$ ) are stronger in smaller atoms, with a corollary that bond dissociation energies should decrease, when $Z$ increases in a definite column in the Periodic Table. This is not the case in many alkaline-earth compounds. Although hexagonal $\mathrm{BeO}$ has $H_{\mathrm{a}} 1 \mathrm{eV}$ higher than $\mathrm{MgO}$, the following cubic oxides go through a shallow maximum at $\mathrm{CaO}$, and $\mathrm{BaO}$ hardly below $\mathrm{MgO}$. The situation is more extreme in rutile-type $\mathrm{MgF}_{2}$ compared to the fluorites $\mathrm{CaF}_{2}, \mathrm{SrF}_{2}$, and $\mathrm{BaF}_{2}$ all having $H_{\mathrm{a}} 0.4 \mathrm{eV}$ higher. The fluorite-type dioxides show increasing heats of atomization for increasing unit cell $\mathrm{a}_{0}$ (and concomitant internuclear distances). Although $\mathrm{ZrO}_{2}$ and $\mathrm{HfO}_{2}$ are low-symmetry (monoclinic) baddeleyites, their thermodynamical stability is known to be almost the same as cubic fluorites. Hence, $H_{\mathrm{a}}$ can be arranged in a series terminating roughly where ru-

$$
\begin{aligned}
& \mathrm{ThO}_{2}>\mathrm{HfO}_{2}>\mathrm{ZrO}_{2}>\mathrm{UO}_{2}>\mathrm{CeO}_{2}> \\
& \mathrm{PuO}_{2}
\end{aligned}
$$

tile $\mathrm{TiO}_{2}$ is situated. It is also striking that $\mathrm{ThF}_{4}>\mathrm{ZrF}_{4}>\mathrm{UF}_{4}$ show the same order; that $\mathrm{UF}_{6}$ has $H_{\mathrm{a}} 70 \%$ higher than the other (far less reactive) molecule $\mathrm{SF}_{6}$; and that large $\mathrm{M}^{\mathrm{III}}$ in $\mathrm{La}_{2} \mathrm{O}_{3}, \mathrm{Nd}_{2} \mathrm{O}_{3}$, and $\mathrm{Lu}_{2} \mathrm{O}_{3}$ above $\mathrm{Al}_{2} \mathrm{O}_{3}$.

The comparison of solid or gaseous oxides and/or fluorides of a familiar oxidation state (frequently the only known [2][3]) with high-temperature molecules with oxidation number +2 in $\mathrm{MO}$ and +1 in MF is not conceptually evident. However, the trend is that $H_{\mathrm{a}}$ with a given element $\mathrm{M}$ are similar in MF and MO (except CF and $\mathrm{CO}$ differing by a factor 2 ). Actually, the diatomic molecules have a plurality of valence orbitals, especially in the beginning of the transition groups. The molecular flame spectra of alkaline-earth $\mathrm{MX}$ $(\mathrm{X}=\mathrm{H}, \mathrm{F}, \mathrm{Cl}, \mathrm{Br}, \mathrm{I})$ exhibit a groundstate [2] with one electron in a rotationally symmetric $\sigma$ orbital (being, $e, g$. in barium, a mixture of $6 \mathrm{~s}, 6 \mathrm{p}, 5 \mathrm{~d}, \ldots$ in LCAO models), which is filled in the singlet groundstate of $\mathrm{MO}$, and [6] in ScF, YF, 
and LaF. Calling this orbital $\sigma$, the ${ }^{3} \Delta$ of $\mathrm{TiO}$ is $(3 \mathrm{~d} \delta)^{1} \sigma^{1}$, and ${ }^{4} \Sigma$ of $\mathrm{VO}(3 \mathrm{~d} \delta)^{2} \sigma^{1}$, going through a gradual evolution toward gaseous $\mathrm{CuO}$ having a full $3 \mathrm{~d}^{10}$ but lacking an electron in a $\pi$ orbital localized on oxygen. The situation is more complicated in lanthanide $\mathrm{LnO}$; thus, $\mathrm{EuO}$ is a genuine $4 \mathrm{f}^{7} \mathrm{Ln}$ " oxide, but $\mathrm{CeO}$ being $4 \mathrm{f}^{1} \sigma^{1}$, GdO $4 \mathrm{f}^{7} \sigma^{1}$ [7-10] (much like the ${ }^{7} \Sigma$ groundstate of $\mathrm{MnH}, \mathrm{MnF}, \mathrm{MnCl}$, and $\mathrm{MnBr}$ being $3 \mathrm{~d}^{5} \sigma^{1}$ systems [6]) and (at least) most of the gaseous $\mathrm{LnF}$ groundstates $4 \mathrm{f}^{\mathrm{q}} \sigma^{2}$.

These aspects of diatomics prepare the reader for a surprising demise of 'ligand field' stabilization [11][12]. $H_{\mathrm{a}}$ is $0.4 \mathrm{eV}$ lower of solid $\mathrm{MnO}$ and $\mathrm{NiO}$ than of the isotypic $\mathrm{MgO}\left(\mathrm{a}_{0}=443.5,417.2\right.$, and 420.3 pm), álmost the same in all three diatomics, and there is a general trend to have the highest $H_{\mathrm{a}}$ in the case of no d-like electrons (in LCAO models, there is, of course, some d-like density [2][12] in the fully occupied, bonding orbitals of appropriate symmetry type), in the $3 \mathrm{~d}^{0} \mathrm{Ca}^{\mathrm{II}}, \mathrm{Sc}^{\mathrm{III}}, \mathrm{Ti}^{\mathrm{IV}}$; $4 \mathrm{~d}^{0} \mathrm{Sr}^{\mathrm{II}}, \mathrm{Y}^{\mathrm{III}}, \mathrm{Zr}^{\mathrm{IV}}$; before the lanthanides $\mathrm{Ba}^{\mathrm{Il}}$ and $\mathrm{La}^{\mathrm{III}}$; and in the $5 \mathrm{f}$ group $\mathrm{Th}^{\mathrm{IV}}$. This paradox is accentuated by the low $H_{\text {a }}$ for Mgll compounds with stronger Madelung potential (due to shorter $\mathrm{Mg}-\mathrm{X}$ ), and forming well-defined aqua ions $\left[\mathrm{M}\left(\mathrm{OH}_{2}\right)_{6}\right]^{+2}$ similar to $\mathrm{Mn}^{\mathrm{II}}, \mathrm{Fe}^{\mathrm{II}}, \mathrm{Co}^{\mathrm{II}}$, and $\mathrm{Ni}^{1+}$.

lt is worthwhile to analyze below (what we colloquially and provisionally call) the Barium-Thorium Effect on atomization energies $H_{\mathrm{a}}$. Why should the very beginning (if not the penultimate $Z=56$ and 90 ) of the $4 \mathrm{f}$ and $5 \mathrm{f}$ group stabilize compounds against complete atomization? Even the beginning of the $5 \mathrm{~d}$ group shows indications too in lutetium, hafnium, and tantalum (Table). One might think about rela- tivistic effects [13] varying energy-wise roughly as $Z^{4} / 137$.

It is established [14] that the non-relativistic Hartree-Fock groundstate predicts $1 \%$ less binding energy $(600 \mathrm{eV})$ than the relativistic wave-function at comparable level of sophistication for $Z=32$ (germanium) and $10 \%$ for $Z=96$ (curium). The total binding energy of the 90 electrons in the Th-atom is enhanced by $57500 \mathrm{eV}$. The relativistic effects [13] are, by far, concentrated on $1 \mathrm{~s}, 2 \mathrm{~s}$ and $2 \mathrm{p}_{1 / 2}$ inner shells, but a compulsory orthogonalization of valence orbitals acquiring $10^{-5}$ squared amplitude provides more than 0.5 $\mathrm{eV}$ each. Pyykkö [13] argues that the high $H_{\mathrm{a}}$ of ThO and UO molecules, and the exclusive behaviour of uranyl chemistry [15-17] hence can be rationalized. Chemically speaking, the most striking result is the difficulty of oxidizing $\mathrm{Au}^{-1}, \mathrm{Tl}^{\mathrm{I}}, \mathrm{Pb}^{\mathrm{II}}$, $\mathrm{Bi}^{\mathrm{III}}$, and $\mathrm{Po}^{\mathrm{IV}}$ which would contain two $6 \mathrm{~s}$ electrons as monatomic species.

Our problem is that $H_{\mathrm{a}}$ express the difference between a novel effect in the compound and in the separated atoms. The metallic elements Mo, Tc, Ru, Rh have $H_{\mathrm{a}} 1$ to $2 \mathrm{eV}$ lower than the homologs $\mathrm{W}, \mathrm{Re}, \mathrm{Os}$ and Ir. This is almost a 'ligand field' tendency [2], octahedral Co ${ }^{\text {III }}, \mathrm{Rh}^{\mathrm{III}}$, and $\mathrm{Ir}^{\mathrm{III}}$ with the same ligands having the anti-bonding tendency $\Delta$ of the two empty, d-like orbitals $\left(x^{2}-y^{2}\right)$ and $\left(3 z^{2}-r^{2}\right)$ in the ratio $1: 1.5: 1.8$. We know [14][18] that the correlation energy $-E_{\text {corr }}$ (indicating the insufficient lowering of the HartreeFock groundstate, where a well-defined electron configuration is presumed) is 1.1 $\mathrm{eV}$ in $\mathrm{He}$ (and the isoelectronic $\mathrm{Li}^{+}, \mathrm{Be}^{+2}$, ..), $2.6 \mathrm{eV}$ in $\mathrm{Be}, 11 \mathrm{eV}$ in $\mathrm{Ne}$, very close to $20 \mathrm{eV}$ in $\mathrm{Ar}$, and not far from $40 \mathrm{eV}$ in $\mathrm{Zn}$ atoms and gaseous $\mathrm{Zn}^{+2}$ [19]. There is no doubt that $-E_{\text {corr }}$ on the average increases by more than the first power of $(Z-1)$, and it was [14][20] suggested

$$
\begin{gathered}
-E_{\text {corr }}=(0.7 \mathrm{eV}) Z^{1.2} \\
E_{\mathrm{G}}=(13.6 \mathrm{eV}) Z^{2.40} .
\end{gathered}
$$

That $-E_{\text {corr }}$ is roughly proportional to the square root of the Gáspár expression [21] for the total binding energy $E_{\mathrm{G}}$ of $Z$ electrons in a neutral atom (it runs 3-2\% lower than the observed value between $Z$ $=6$ and 46, and, for relativistic reasons, $6.3-8.3 \%$ too low between $Z=80$ and 90 ; if the Rydberg constant is replaced by a free parameter, it might be $14.0 \mathrm{eV}$ ). It is not argued [14][18] that $-E_{\text {corr }}$ is strictly monotonic with $Z$, but it is likely to be well represented within a factor 1.3.

The correlation energy is very tiny, compared to the total $E_{\mathrm{G}}$ (it is $0.3 \%$ for $Z$ $=10 ; 0.09 \%$ for $Z=30$; and $0.04 \%$ for $Z=$ $60)$. However, the most interesting aspect for the chemist is the pronounced decrease of the 'squamp' (the squared amplitude of the Hartree-Fock wave-function in the exact non-relativistic Schrödinger solution for the ground state) known[18][19] to be 0.992 in the He-atom, and close to 0.92 in Ne. An (admittedly quite approximate) second-order argument (p. 283 of [20]) equates (1-'squamp') with $-E_{\text {corr }}$ $\left(2 I_{k}\right)$ where $I_{\mathrm{k}}$ is a representative average of the excitation energy $I_{\mathrm{k}}$ of each of the two electrons substituting the ground electron configuration (as shown by Löwdin in 1959 to be the major mechanism of $-E_{\text {corr }}$ ) in a variety of high-energy configurations having optimized squares of the non-diagonal elements of interelectronic repulsion with the Hartree-Fock ground configuration. The estimated 'squamp' values around 0.7 for $Z=30$ (zinc) and 0.4 for $Z$

Table. Heat of Atomization $\mathrm{H}_{a}$ in eV $(=96487 \mathrm{Joule} / \mathrm{mol}=23061 \mathrm{cal} / \mathrm{mol})$ for Solid (and a few gaseous) Polyatomic Oxides and Fluorides, and for Similar

\begin{tabular}{|c|c|c|c|c|c|c|c|c|c|c|c|}
\hline \multirow{2}{*}{$\begin{array}{l}\text { Polyatomic } \\
\mathrm{BeO} \text { (c) }\end{array}$} & \multirow[b]{2}{*}{6.14} & \multirow{2}{*}{$\begin{array}{l}\text { Diatomic } \\
\mathrm{BeO}\end{array}$} & \multirow[b]{2}{*}{2.25} & \multirow{2}{*}{$\begin{array}{l}\text { Polyatomic } \\
\mathrm{BaO}[\mathrm{NaCl}]\end{array}$} & \multirow[b]{2}{*}{5.11} & \multicolumn{2}{|c|}{ Diatomic } & \multicolumn{2}{|l|}{ Polyatomic } & \multicolumn{2}{|c|}{ Diatomic } \\
\hline & & & & & & $\mathrm{BaO}$ & 2.91 & $\mathrm{LiF}[\mathrm{NaCl}]$ & 4.43 & HF & 2.96 \\
\hline $\mathrm{CO}_{2}(\mathrm{~g})$ & 5.57 & BO & 4.18 & $\mathrm{La}_{2} \mathrm{O}_{3}(\mathrm{c})$ & 7.06 & $\mathrm{LaO}$ & 4.14 & $\mathrm{BF}_{3}(\mathrm{~g})$ & 5.01 & LiF & 3.0 \\
\hline $\mathrm{MgO}[\mathrm{NaCl}]$ & 5.17 & $\mathrm{CO}$ & 5.58 & $\mathrm{CeO}_{2}\left[\mathrm{CaF}_{2}\right]$ & 6.93 & $\mathrm{CeO}$ & 4.12 & $\mathrm{CF}_{4}(\mathrm{~g})$ & 4.07 & $\mathrm{BF}$ & 3.97 \\
\hline $\mathrm{Al}_{2} \mathrm{O}_{3}(\mathrm{c})$ & 6.37 & $\mathrm{MgO}$ & 1.88 & $\mathrm{Nd}_{2} \mathrm{O}_{3}$ (c) & 6.66 & $\mathrm{NdO}$ & 3.65 & $\mathrm{NaF}[\mathrm{NaCl}]$ & 3.93 & CF & 2.86 \\
\hline $\mathrm{SiO}_{2}(\mathrm{c})$ & 6.45 & $\mathrm{AlO}$ & 2.65 & $\mathrm{Lu}_{2} \mathrm{O}_{3}(\mathrm{c})$ & 7.22 & GdO & 3.73 & $\mathrm{MgF}_{2}(\mathrm{c})$ & 4.93 & $\mathrm{NaF}$ & 2.7 \\
\hline $\mathrm{CaO}[\mathrm{NaCl}]$ & 5.51 & $\mathrm{SiO}$ & 4.14 & $\mathrm{HfO}_{2}(\mathrm{c})$ & 7.79 & ErO & 3.19 & $\mathrm{SiF}_{4}(\mathrm{~g})$ & 4.95 & $\mathrm{MgF}$ & 2.39 \\
\hline $\mathrm{TiO}_{2}(\mathrm{c})$ & 6.61 & $\mathrm{ScO}$ & 3.53 & $\mathrm{Ta}_{2} \mathrm{O}_{5}(\mathrm{c})$ & 7.20 & $\mathrm{LuO}$ & 3.51 & $\mathrm{SF}_{6}(\mathrm{~g})$ & 2.91 & AlF & 3.44 \\
\hline $\mathrm{MnO}[\mathrm{NaCl}]$ & 4.75 & $\mathrm{TiO}$ & 3.49 & $\mathrm{WO}_{3}(\mathrm{c})$ & 6.32 & HfO & 4.16 & $\mathrm{CaF}_{2}\left[\mathrm{CaF}_{2}\right]$ & 5.36 & $\mathrm{CaF}$ & 2.73 \\
\hline $\mathrm{NiO}[\mathrm{NaCl}]$ & 4.77 & $\mathrm{MnO}$ & 2.1 & $\mathrm{OsO}_{4}(\mathrm{~g})$ & 4.42 & $\mathrm{TaO}$ & 4.14 & $\mathrm{SrF}_{2}\left[\mathrm{CaF}_{2}\right]$ & 5.32 & $\mathrm{SrF}$ & 2.81 \\
\hline $\mathrm{ZnO}(\mathrm{c})$ & 3.77 & $\mathrm{NiO}$ & 2.03 & $\mathrm{PbO}(\mathrm{c})$ & 3.44 & WO & 3.5 & $\mathrm{ZrF}_{4}(\mathrm{c})$ & 5.78 & YF & 3.14 \\
\hline $\mathrm{SrO}[\mathrm{NaCl}]$ & 5.20 & YO & 3.71 & $\mathrm{ThO}_{2}\left[\mathrm{CaF}_{2}\right]$ & 8.02 & $\mathrm{PbO}$ & 1.98 & $\mathrm{BaF}_{2}\left[\mathrm{CaF}_{2}\right]$ & 5.34 & $\mathrm{BaF}$ & 3.04 \\
\hline $\mathrm{ZrO}_{2}(\mathrm{c})$ & 7.63 & $\mathrm{ZrO}$ & 4.02 & $\mathrm{UO}_{2}\left[\mathrm{CaF}_{2}\right]$ & 7.32 & ThO & 4.55 & $\mathrm{ThF}_{4}(\mathrm{c})$ & 6.23 & $\mathrm{NdF}$ & 2.82 \\
\hline $\mathrm{MoO}_{3}(\mathrm{c})$ & 5.57 & $\mathrm{NbO}$ & 4.00 & $\mathrm{UO}_{3}(\mathrm{c})$ & 6.49 & UO & 3.94 & $\mathrm{UF}_{4}(\mathrm{c})$ & 5.75 & $\mathrm{ErF}$ & 2.93 \\
\hline $\mathrm{SnO}_{2}(\mathrm{c})$ & 4.77 & $\mathrm{SnO}$ & 2.76 & $\mathrm{PuO}_{2}\left[\mathrm{CaF}_{2}\right]$ & 6.54 & NpO & 3.73 & $\mathrm{UF}_{6}(\mathrm{~g})$ & 4.75 & UF & 3.42 \\
\hline
\end{tabular}
Gaseous Diatomic $M O$ and $M F$. Crystalline compounds are marked (c) except the cubic types $[\mathrm{NaCl}]$ and $\left[\mathrm{CaF}_{2}\right]$. 
CHIMIA 46 (1992) Nr. 11 (November)

$=60$ (neodymium) decrease roughly linearly as $(1-0.01 Z)$. It is not essential that these estimates may be wrong by a factor 1.2 or 0.8 ; in all scenarios, the HartreeFock wave-function is not a good approximation to the $3 K$-dimensional Schrödinger solution [18] for an atom with $K$ higher than 20 , that is more electrons than $\mathrm{Ca}^{0}$ or $\mathrm{Fe}^{+6}$.

The chemist notes that $-E_{\text {corr }}$ depends mainly on loosely bound orbitals (having one-electron energies far less negative than $E_{\mathrm{G}}$ in Eqn. 4 divided by Z) much like chemical bonding occurring in the valence shells. It is not surprising that $-E_{\text {corr }}$ can be strongly enhanced in a compound compared to its constituent atoms. Only recently, precise $-E_{\text {corr }}$ have become available for molecules with 2-5 nuclei having one-digit $Z$ values [22][23] such as the isoelectronic $\mathrm{N}_{2}(5.17), \mathrm{CO}(3.78)$, and $\mathrm{BF}(2.12)$ where the difference between $-E_{\text {corr }}$ of the molecule and the sum over the isolated atoms is given in $\mathrm{eV}$. Said in other words, half of $2 \mathrm{H}_{\mathrm{u}}=9.80 \mathrm{eV}$ in $\mathrm{N}_{2}$ is due to correlation effects. The Hartree-Fock function of $F_{2}$ does not predict bonding, - $E_{\text {corr }}[22]$ is $3.64 \mathrm{eV}$ (above $8.87 \mathrm{eV}$ for each of the two $\mathrm{F}^{0}$ ), larger than $2 \mathrm{H}_{\mathrm{a}}=1.69$ $\mathrm{eV}$. Among the examples [22], linear OCO has the highest additional $-E_{\text {corr }}=6.4 \mathrm{eV}$ $(=0.38$ times the atomization energy 16.7 $\mathrm{eV}$ ). It is thought-provoking [24] that the elaborate Gaussian-l procedure of Pople predicts atomization energies (per molecule, all $Z$ below 18 , and up to 30 electrons) usually deviating $0.1 \mathrm{eV}$ from the available, accurate experimental heats of atomization. Though this treatment does not imply energy differences between the non-relativistic Schrödinger eigen-values for the molecul and for the isolated atoms, it may give some hope for estimates of $-E_{\text {corr }}$ Nesbet [25] further discussed electron correlation in atoms, molecules and solids in a Festschrift for John Pople.

There is experimental evidence for strong chemical modification of $-E_{\text {corr }}$ from XPES [26][27], e.g. the various inner shells of $\mathrm{Mg}^{0}, \mathrm{Ca}^{0}, \mathrm{Sr}^{0}, \mathrm{Ba}^{0}$, and $\mathrm{Hg}^{0}$ decrease all ionization energies by a value (for a given $Z$ ) between 3 and $8 \mathrm{eV}$ by condensation to the metallic element [28]. The 'barium-thorium effect' on $H_{\mathrm{a}}$ influences the enthalpy difference between the compound and the separated gaseous atoms. Even if we knew that $-E_{\text {corr }}$ was exactly $80 \mathrm{eV}$ for $\mathrm{Ba}^{0}$ and $150 \mathrm{eV}$ for $\mathrm{Th}^{0}$ it would not solve our problem. Since molecular orbitals of the LCAO type occur in a configuration with its 'squamp' at most 0.5 , and conceivably only 0.2 (extrapolating from $\mathrm{N}_{2}$ and $\mathrm{CO}$ ) the atomic orbitals in an optimized LCAO description of electronic density may be modified in the compound, acquiring more $1 \mathrm{~s}, 2 \mathrm{~s}$,
$3 \mathrm{~s}, \ldots$ character than the gaseous atom. Another, more general, situation is 'chemical polarization' effects [29]; however, they are synonymous with 'partly covalent bonding' to some extent. It should not be neglected that the energies and the positions of the Born-Oppenheimer potential curve minima for a diatomic, or the $(3 N-5)$ dimensional surface for $N$ nuclei [18] nuclei are both influenced by relativistic effects (such as $\mathrm{F}_{2}$ dissociating in the Hartree-Fock model).

A quite curious fact is that gaseous $\mathrm{BaF}_{2}, \mathrm{BaCl}_{2}, \mathrm{BaBr}_{2}, \mathrm{SrF}_{2}, \mathrm{SrCl}_{2}$, and $\mathrm{CaF}_{2}$ are bent (angle $\mathrm{XMX}$ below $180^{\circ}$ ) but $\mathrm{CaCl}_{2}, \mathrm{CaBr}_{2}, \mathrm{SrBr}_{2}$, and $\mathrm{SrI}_{2}$ are linear [30] like FMF for $\mathrm{M}=\mathrm{Mn}, \mathrm{Co}, \mathrm{Ni}, \mathrm{Cu}, \mathrm{Zn}$. For some unknown reason, bending occurs when the ratio $r\left(\mathrm{M}^{+2}\right) / r\left(\mathrm{X}^{-}\right)$between Goldschmidt ionic radii is above 0.68 . By the way, $\mathrm{ThO}_{2}$ molecules in a cool $\mathrm{Ar}$ matrix has also been reported [31] to be bent $\left(122^{\circ}\right)$ in contrast to the strictly linear uranyl ion $\mathrm{OUO}^{+2}[15][16]$. Like several other $\mathrm{Ar}^{0}$ complexes [32] [33], bent $\mathrm{CeO}_{2}$ and $\mathrm{ThO}_{2}$ could be $\mathrm{Ar}_{\mathrm{x}} \mathrm{CeO}_{2}$ and $\mathrm{Ar}_{\mathrm{Y}} \mathrm{ThO}_{2}$ in analogy to $\mathrm{ArCr}(\mathrm{CO})_{5}$ and $\mathrm{Ar}_{2} \mathrm{Cr}(\mathrm{NN})_{4}$. This situation differs from isolated $\mathrm{NO}_{2}^{-}$, $\mathrm{NO}_{2}, \mathrm{O}_{3}^{-}$, and $\mathrm{O}_{3}$ not being linear (as are $\mathrm{OCO}, \mathrm{NCO}^{-}, \mathrm{NCN}^{-2}, \mathrm{NNN}^{-}, \mathrm{NNO}$, and $\mathrm{ONO}^{+}$). It is not easy with quantum chemistry alone to rationalize the tendency of $\mathrm{Ba}^{\mathrm{II}}, \mathrm{La}^{\mathrm{IlI}}$, to some extent $\mathrm{Lu}^{\mathrm{III}}$ and $\mathrm{Hf}^{\mathrm{IV}}$, and distinctly $\mathrm{Th}^{\mathrm{IV}}, \mathrm{U}^{\mathrm{IV}}$, and $\mathrm{U}^{\mathrm{VI}}$ compounds to show $H_{\mathrm{a}}$ values at least some 1$2 \mathrm{eV}$ higher (per atom in the compound) than expected for smaller ions in the same oxidation state. The low $H_{\mathrm{a}}$ for $\mathrm{Zn}^{\mathrm{II}}, \mathrm{Sn}^{\mathrm{IV}}$, and $\mathrm{Pb}^{\mathrm{II}}$ compounds do not suggest a monotonic variation with $Z$, also since $\mathrm{Sr}^{\mathrm{Il}}$ and $\mathrm{Y}^{\mathrm{III}}$ already show a weak 'bariumthorium effect'.

The scenario of differential $-E_{\text {corr }}$ on forming compounds fits the low $H$ for compounds containing a partly filled $3 \mathrm{~d}$, $4 \mathrm{~d}, 4 \mathrm{f}$, or $5 \mathrm{f}$ shell. The oxidation states [2][3] $\mathrm{Zr}^{\mathrm{IV}}, \mathrm{Hf}^{\mathrm{IV}}, \mathrm{Ta}^{\mathrm{v}}, \mathrm{W}^{\mathrm{VI}}$, and Os ${ }^{\mathrm{VIII}}$ correspond to $\mathrm{d}^{0}$ systems. Gaseous atoms with partly filled $\mathrm{d}$ or $\mathrm{f}$ shells may have enlarged opportunities for two-electron substitutions [19][20] increasing their $-E_{\text {corr }}$ (contributing to lower $H_{\mathrm{a}}$ ), and compounds at the beginning of transition groups may increase $-E_{\text {corr }}$ due to a large number of empty orbitals efficient in the compound. The 'barium-thorium effect' is not much more conspicuous in oxides than in fluorides, rendering electronegativity [18], polarizability [29] and quasi-metallicity [1] less attractive tools of argumentation.

I am grateful for extensive discussions with Prof. Claus E. Schäffer on inductive chemistry. Our collaboration was furthered by grant 20.27938 .89 from the Swiss National Science Foundation.
Received: September 17, 1991 Revised: July 30, 1992

[1] C.K. Jørgensen, Topics Cur. Chem. 1989, $150,1$.

[2] C.K. Jørgensen, 'Oxidation Numbers and Oxidation States', Springer, Berlin - New York, 1969.

[3] C.K.Jørgensen, Z.Anorg.Allg.Chem. 1986, $540,91$.

[4] R.C. Weast, 'CRC Handbook of Chemistry and Physics', 70th edn., CRC Press, Boca Raton, Florida, 1990.

[5] K. Hilpert, Struct. Bonding 1990, 73, 97.

[6] C.K. Jørgensen, Mol. Phys. 1964, 7, 417.

[7] R.W. Field, Ber.Bunsen-Ges. Phys. Chem. $1982,86,771$.

[8] M. Dolg, H. Stoll, H. Preuss, J. Chem. Phys. 1989, 90, 1730.

[9] M. Dolg, H. Stoll, H. Preuss, Chem. Phys. Lett. 1990, 174, 208.

[10] M. Kotzian, N. Rösch, Eur. J. Solid Siate Inorg. Chem. 1991, 28, 127.

[11] P. George, D.S. Mc Clure, Progr. Inorg. Chem. 1959, l, 381 .

[12] C.K. Jørgensen, 'Modern Aspects of Ligand Field Theory', North-Holland, Amsterdam, 1971.

[13] P. Pyykkö, Chem. Rev. 1988, 88, 563.

[14] C.K. Jørgensen, Chimia 1988, 42, 21.

[15] C.K. Jørgensen, R. Reisfeld, Struct. Bonding 1982, 50, 121

[16] C.K. Jørgensen, R. Reisfeld, J. Electrochem. Soc. 1983, 130, 681.

[17] R.L. De Kock, E.J. Baerends, P.M, Boerrigter, J.G. Snijders, Chem. Phys. Lett. 1984, IOS, 308.

[18] C.K. Jørgensen, Comments Inorg. Chem. 1991, $12,139$.

[19] C.K. Jørgensen, Solid State Phys. 1962,13, 375.

[20] C.K. Jørgensen, in 'Handbook on the Physics and Chemistry of Rare Earths', Eds, K.A. Gschneidner and L. Eyring, NorthHolland, Amsterdam, 1988, Vol. 11, p. 197-292.

[21] R. Gáspár, Int.J. Quantum Chem. 1967, I, 139.

[22] J. Robles, G. Kemister, Chent. Phys. Lett. 1987, 134, 27.

[23] W. Klopper, R. Röhse, W. Kutzelnigg, Chem. Phys. Lett. 1991, $178,455$.

[24] L.A. Curtiss, C. Jones, G.W. Trucks, K. Raghavachari, J. Pople, J. Chem. Phys. 1990, 93, 2537.

[25] R.K. Nesbet, J. Phys. Chem. 1990, 94, 5444.

[26] C.K. Jørgensen, Adv, Quantum Chem. 1974, 8,137 ; ibid. 1978, 11,51 .

[27] C.K. Jørgensen, Struct. Bonding 1975, 24, 1; ibid. 1976, 30, 141 .

[28] J.S.H.Q. Perera, D.C. Frost, C.A. Mc Dowell, C.S. Ewig, R.J. Key, M.S. Banna, $J$. Chem. Phys, 1982, 77, 3308.

[29] C.K. Jørgensen, Topics Curr. Chem. 1975, $56,1$.

[30] L. Wharton, R.A. Berg, W. Klemperer, $J$. Chem. Phys. 1963, 39, 2023.

[31] S.D. Gabelnick, G.T. Reedy, M.G. Chasnanov, J. Chem. Phys. 1974, 60, 1167.

[32] C.K. Jørgensen, Chem. Phys. Lett. 1988 , IS3, 185.

[33] C.K. Jørgensen, G. Frenking, Struct. Bonding $1990,73,1$. 